DOI: 10.46340/ephd.2021.7.2.4

Dmytro Treitiak

ORCID ID: https://orcid.org/0000-0003-3909-5062

National Pedagogical Dragomanov University, Kyiv, Ukraine

\title{
COLLECTIVIZATION AS A DISASTER \\ OF THE ECONOMIC ORDER OF THE PEASANT POPULATION OF THE GREEKS OF PRYAZOVIA
}

\author{
Дмитро Трейтяк \\ Начіональний педагогічний університет імені М.П. Драгоманова, м. Київ, Україна
}

\section{КОЛЕКТИВІЗАЦІЯ ЯК КАТАСТРОФА ГОСПОДАРСЬКОГО ЛАДУ СЕЛЯНСЬКОГО НАСЕЛЕННЯ ГРЕКІВ ПРИАЗОВ'Я}

The article reveals the peculiarities of the collectivization by the Soviet authorities in the Greek villages of the Azov region in the late 1920s and early 1930s. In the context of the study of the daily life of the Greek ethnic minority, an important aspect is the disclosure of the social and economic factors that influence the everyday reality. A significant event of the Soviet era of the 20 s and 30s was the mass collectivization that took place in the country. The local population, which was trying to resist the loss of their property earned over the years, fully felt the pressure of the repressive Soviet machine. This article reveals the scale of the economic catastrophe suffered by ordinary Greek families in the Azov region as a result of collectivization in the region. The purpose of this study is to analyze the catastrophic consequences of collectivization in the $20 \mathrm{~s}$ and $30 \mathrm{~s}$ for Greek farms. The article examines the features of the first stages of collectivization, the reasons for the slow pace of their implementation, and the harsh reaction of the Soviet authorities to this. Details of the destructive impact of Soviet collectivization measures are revealed on the economy of Greek families. Various means of influencing the peasants, which were used by the Soviet local leadership, and the features of the forced involvement of peasants in collective farms are described. The peculiarities of repressive measures against the wealthiest sections of the Greek population and against ordinary Greek peasant families in the Azov region have been studied. Examples of the Soviet government's repressive actions against ordinary Greek peasants are given. The peculiarities of Soviet propaganda, which praised the alleged extraordinary successes of collectivization, and the contrast about the real difficult situation in the region, are revealed. The results of collectivization and their reflection on Greek peasant society are determined.

Keywords: Greeks of the Azov region, collectivization, collective farm, Greek national districts, dekulakization.

Масова колективізація, що проводилася на території радянського союзу, стала складним випробуванням для мільйонів селян, і грецькі селяни Приазов'я також постраждали від неї. Серед досліджень, які зверталися саме до питання колективізації селянського населення Приазов'я, та репресивних дій влади проти незгодних, були такі автори як: Л.Якубова ${ }^{1}$, Л. Насєдкіна ${ }^{2}$, О. Обидьонова. Матеріали, які висвітлюють процеси колективізації, зустрічаємо у «Історія повсякденності в її етнічному вимірі: спогади грека-комуніста» І. Стріонова. Про насильницьку політику залучення селян до колгоспів розповідається в виданні «Малоянисоль: история, события,

\footnotetext{
${ }^{1}$ Якубова, Л. Д. (2004). Суцільна колективізація в селах етнічних меншин. 1930-1935 рр. Проблеми історії України: факти, судження, пошуки. Київ: Інститут історії України НАН України, 11, 370-412.

${ }^{2}$ Наседкіна, Л. Д. (1992). Грецькі національні сільради та райони в Україні (друга половина 20-х-30-ті роки ХХ століття). Український історичний журнал, 6, 64-72.
} 
судьбы (1780-2010)» Е. Аніміци. В документах ЦДАВО України можна знайти чимало статистичних відомостей, щодо проведення колективізації, які дають уявлення про масштаби та деталі процесу.

Після складних років громадянської війни та голоду початку 20 -х років, грецьке селянство Приазов'я поступово приходило до тями. Серед селянського населення почали виділятися більш заможні господарства та менш заможні, частина селян взагалі не мала своїх господарств і була змушена працювати у наймах.

У кінці 1927 року на XV з’їзді ВКП(б) було прийнято план по колективізації сільського господарства. Було визначено пріоритетним створення артілей - колективних господарств, які мали стати перехідними на шляху до комун. Земля та засоби ії обробітку повинні були стати колективною власністю. Колективні господарства - колгоспи та радгоспи - мали здавати отриманий врожай державі.

Після цього розпочалося прискорене впровадження колективізації в селах, в тому числі і грецьких селах. Державна політика Радянського Союзу передбачала об'єднання господарств дрібного та середнього селянства та ліквідацію заможних селянських господарств. Заплановані перетворення у галузі сільського господарства передбачали створення колгоспів - колективних господарств, які мали спеціалізуватися на садівництві, виноградарстві та городництві, а також відкриття невеликих підприємств по переробці продукції, відкриття машинно-тракторних станцій. Масове запровадження колективізації стало складним випробуванням для багатьох представників національних меншини, в тому числі і для греків. Спочатку воно відбувалося відносно мирним шляхом, проте з часом радянське керівництво, розуміючи що населення пручається втраті роками заробленої власності, почало вдаватися до насильницьких та примусових методів. Ще одним із завдань, які ставила перед собою комуністична влада, було намагання підвищити рівень ворожнечі всередині окремих громад, сприяючи тому, щоб у найбідніших верств селянства формувалося максимально негативне ставлення до заможних прошарків населення. Коли розпочалася колективізація, в середині 20-х років, у багатьох грецьких селищах термін «колективне господарство» ще не мав точно такого значення, якого він набув пізніше. Перші колгоспи організовувалися у вигляді спільних комун. Наприклад, у селищі Малоянісоль у 1925 році була заснована перша комуна. Ця спроба була невдалою і на зміну комуні прийшли так звані «товариства по спільній обробці землі» (ТО3) та «союзі по спільній обробці землі» (СО3). В цих організаціях залишалася роздільна власність. У 1928 році в Малоянісолі було створено три СОЗи. Ці організації отримали по одному трактору, що стало одними з перших випадків запровадження механізації землеобробітку ${ }^{1}$.

У розквіт соціалістичної агітації про трудові змагання, передовиків збору врожаю, або виконання подвійної чи потрійної норми на заводі, стали нормою хвалебні статті в газетах чи оголошення про трудові зрушення. Проте насправді ситуація в селах залишалася вкрай складною. Умови роботи в колгоспах та радгоспах залишалася непростими. Існували труднощі із запровадженням багатопільних сівозмін та городництва. Надзвичайно важко доводилося мешканцям малих сіл та хуторів - подекуди їм доводилося долати великі відстані для того щоб придбати товари першої необхідності, такі як хліб або сірники. Жителі більш великих поселень часто також страждали від дефіциту товарів ${ }^{2}$.

У 1929 році XVI партійна конференція поставила вимогу прискорити процеси колективізації в країні. Так само після цієї конференції розпочався активний наступ на «кулацтво»- елемент заможного селянства. Такими селянами були більш багаті люди, які використовували працю найманих робітників. Вони могли завдяки прибуткам від господарства продавати надлишок продукції, який залишався після здачі продподатку, і таким чином отримати додатковий прибуток. Іноді це були навіть не дуже заможні люди, які за рахунок правильного ведення господарства або вдалого урожаю ставали більш забезпеченими, ніж їхні сусіди. Саме вони отримали ярлик кулаків, проти яких велася політика радянського уряду під час колективізації. Метою радянської влади було дискредитувати індивідуальний шлях до прибутків і примусити селян-середняків масово вступати до колективних господарств³.

\footnotetext{
${ }^{1}$ Анимица, Е. Г., Антонова, Л. Г. (2010). Малоянисоль: история, события, судьбы (1780-2010). Екатеринбург: Издательство Уральского государственного экономического университета, 120.

2 Якубова, Л. Д. (2011). Повсякденне життя етнічних меншин радянської України у міжвоєнну добу. Київ: Інститут історії України, 289.

${ }^{3}$ Анимица, Е. Г., Антонова, Л. Г. (2010). Малоянисоль: история, события, судьбы (1780-2010). Екатеринбург: Издательство Уральского государственного экономического университета, 125.
} 
Оскільки багато селян не бажало добровільно вступати до колгоспів, їх почали силою примушувати робити це. Вступ до колгоспу вимушував селянина здавати у колективне господарство своє майно - коней, корів, птицю, овець та іншу худобу, навіть сільськогосподарський інвентар. Приклад агітації до вступу в колгосп знаходимо у С.К. Темира. Він розповідає: «По селу ходив учитель на прізвище Хорош. Спочатку він читав газети, знайомив слухачів з останніми новинами, а потім приступав до головного. Перше питання завжди було одне: «Хто запишеться до колгоспу»? У кімнаті- мертва тиша. Друге питання: «Хто скільки зерна здасть на користь держави»? Знову тиша. Тоді агітатор звертався персонально до кожного 3 тими ж питаннями. Якщо і це не давало результату, тоді Хорош і комсомольці, що прийшли разом з ними, переходили в іншу кімнату і викликали туди присутніх по одному. Питання були ті самі. Якщо відмова була повною, комсомольці йшли до цього хазяїна додому. Все знайдене там зерно, а іноді і борошно, відбирали начисто і відправляли до державної комори. Вони не шкодували ні дітей, ні старих, залишали їх без шматка хліба і без насіння для посіву ${ }^{1}$.

Отже, більшість селян не бажали добровільно вступати до колгоспів, оскільки при цьому селянин мав здати весь свій сільськогосподарський інвентар, корів, коней, птицю, тобто повністю позбавлявся майна. Селянин втрачав можливість працювати на своїй землі, що позбавляло його колишньої можливості вести власне господарство. Крім того, організовувалися колгоспи за рахунок коштів, які також жертвували селяни, які вступали до них.

Оскільки селянство зовсім не поспішало позбавлятися нажитої власності та переходити на комуністичний режим господарства, то дуже скоро сільрадівське та районне керівництво почало вдаватися до більш дієвих методів, ніж просто агітаційні промови. У спогадах І.Стріонова можемо зустріти опис того, яким чином місцеве керівництво намагалося примусити селян записуватися до коллективних господарств. «Місцеві власті, що безпосередньо займалися колективізацією, почали тиснути на селян, застосовуючи різні форми насилля. Однією з таких форм примусу було продовження загальних зборів до 10-11 години вечора. В дверях приміщень, де проводилися збори, стояли ломуси з сільських активів і не випускали з приміщення нікого без дозволу президії зборів. Селяни, а особливо селянки, плакали й благали президію зборів, аби їх відпустили додому хоча б погодувати дітей та худобу...»².

Невеликий приток людей до колгоспів відбувався за рахунок наймитів та селян-бідняків. Таким людям майже не було чого втрачати, і тому вони першими записувалися до колгоспів. Проте цього було недостатньо для ефективного проведення колективізації. Пройшло небагато часу, i радянському керівництву стало очевидно, що середняки так просто добровільно не відмовляться від свого майна і не будуть масово вступати до колгоспів. В хід пішли методи залякування та насильної конфіскації майна.

Розпочалася боротьба з кулацтвом як класом. Селян, які виявляли найбільший опір проти розкулачення, висилали до таборів як шкідників та ворогів народу. Інших, які не чинили опору, проте мали статок, висилали разом із сім'ями до віддалених сибірських регіонів. 3 кулаками зобов'язали боротися усі верстви населення, тих, хто не підтримував таку боротьбу, самих звинувачували у шпигунстві і відправляли до заслання.

У роботі по історії села Малоянісоль зустрічаємо приклади таких селян: «Іван Федорович Аріх в період НЕПу зумів нажити невеликий статок. У нього у володінні перебувало 21 десятина землі, він мав 6 корів, трьох коней і 200 голів овець. Своїх рук і рук дружини не вистачало (в сім'ї було шестеро малолітніх дітей), і їм довелося користуватися працею наймита. Зрештою він потрапив до списку осіб яких мали «ліквідовувати у рамках боротьби з кулацтвом». Типовий кулак другої категорії Сергій Костянтинович Пупа. Його сім'я складалася з десяти чоловік, з них вісім дітей. Радянська влада забрала у нього будинок, дві корови, коня, віз, плуг. Всю сім'ю було примусово вислано до Сибіру»³.

Подібним чином від розкулачення постраждало чимало грецьких родин, які мешкали у Приазов 'ї. Їх майно було вилучено, розпродано, а їх самих засилали до віддалених регіонів СРСР Сибіру, Північного Уралу. Греки як більш заможна частина селянства понесли найбільші втрати,

\footnotetext{
${ }^{1}$ Темир, С. К. (2007). Очерки об истории села Старомльновка. Мариуполь: Федерация греческих обществ Украины, 12.

2 Якубова, Л. (ред.) (2008). Історія повсякденності в ї̈ етнічному вимірі: спогади грека-комуніста. Київ.

${ }^{3}$ Анимица, Е. Г., Антонова, Л. Г. (2010). Малоянисоль: история, события, судьбы (1780-2010). Екатеринбург: Издательство Уральского государственного экономического университета, 128.
} 
у деяких приазовських населених пунктах, наприклад, Малому Янісолі, було розкулачено більшу частину селянства.

Масова колективізація та вилучення майна стали причиною відтоку людей з колись багатих селищ Приазов'я. Люди йшли на Донбас, намагаючись влаштуватися працювати у шахти, деякі виїжджали на Кубань ${ }^{1}$. Деякі грецькі села спорожніли, у колгоспах почало не вистачати робочих рук. Радянська влада намагалася вирішити це питання за допомогою переселенців із північних областей УРСР.

Досліджуючи звіти про грецькі національні райони, можна зробити деякі висновки про темпи колективізації, а також про характерні тенденції, що спостерігалися урегіонах з грецьким населенням.

Так, у звіті про роботу серед національних меншостей наводяться дані про стан колективізації на вересень 1929 року. Всього колгоспів нараховувалося 37 (6 комун, 15 артілей, 16 господарств СОЗ), вони об'єднували 824 господарства, що становило $15.6 \%$ від усіх господарств по окрузі. Крім того, в регіоні існували 8 машинно-тракторних товариств, 1 садово-городне товариство, 1 бджільниче товариство, 3 скотарсько-молочних товариства. Зазначалося, що колективізація грецького населення проходила набагато більшими темпами, ніж серед інших національностей округуㄹ․

Дані про стан колективізації по Сартанському району станом на 1928 рік такі. На 1 жовтня 1928 року в районі нараховувалось три колективи - «Комунар» «Незаможник» і «Універсаль». В них тривало розширення господарства, в «Комунарі» було стадо молочних корів, яке нараховувало 23 корови, в перспективі планувалося розширення до 54 корів. Також в районі існувало два спеціальних тваринних товариства - в Сартані та в Чермалику. Сартанське скотарськомолочарське товариство було організовано у грудні 1927 року і нараховувало станом на 1928 рік 193 члени. До району діяльності товариства входило 24 населені пункти, майже вся південно-західна частина адміністративного району. Всі населені пункти товариство не охоплювало, проте активно займалося племінною роботою, збором по селам молока, члени товариства майже за рік діяльності здали 47484 літри молока, частина з цього об’єму була направлена до молочар союзу у сирому вигляді, частина пішла на виробництво молочнокислих продуктів, всі члени союзу отримували гроші за здане молоко у перерахунки на жирність ${ }^{3}$.

На початок 1930 року було колективізовано $29 \%$ усіх господарств грецького населення. Грецькі селяни зазвичай були більш заможними, ніж українці та росіяни, і тому вони більше постраждали під час колективізації, стосовно них було застосовано більш жорстке розкуркулення. Багато заможних греків оголошували куркулями і відправляли у віддалені регіони - до Узбекистану, Казахстану, на Урал ${ }^{4}$.

Мангуський район станом на квітень 1931 року був колективізований на $80 \%{ }^{5}$, (проте такі цифри можуть бути трохи завищеними для звіту. В акті про обстеження села Ялта Мангуського району від 12 квітня 1931 року зазначалося про те, що село було колективізовано на той момент на 78\%. В селі розміщувалася артіль «Красный кирпичик» та рибацька артіль, а також два колгоспи та машинно-тракторна станція 6 .

Інтенсивне проведення колективізації також вплинуло і на особливості традиційної грецької садиби, яка до початку 30-х років дуже довгий не зазнавала значних змін. 3 початком колективізації зникла необхідність у клунях, де раніше зберігалося зерно, адже в селах почали з'являтися колгоспи, будувалися господарські приміщення для загального збору врожаю. В подальшому у більшості грецьких садиб відбувалися зміни, пов'язані з пристосуванням населення до нового способу ведення господарства.

\footnotetext{
${ }^{1}$ Патриляк, Б. К. (2011). Селянський опір колективізаційним заходам радянської влади в УСРР у 1931-1932рр. Гілея: Науковий вісник: збірник наукових праџь, 52, 30.

${ }^{2}$ Центральний державний архів вищих органів влади та управління України. Ф. 413, On. 1, Cnp. 444. 1929.

${ }^{3}$ Центральний державний архів вищих органів влади та управління України. Ф. 413, On. 1, Cnp. 463. Apк. 64. 1929.

${ }^{4}$ Дмитрієнко, М., Литвин, В., Томозов, В., Яковлєва, Л., Ясь, О. (2000). Греки на украӥнських теренах: нариси з етнічної історії. Київ: Либідь, 95.

${ }^{5}$ Центральний державний архів вищих органів влади та управління України. Ф. 413, On. 1, Cnp. 557. Apк. 359. 1931.

${ }^{6}$ Центральний державний архів вищих органів влади та управління України. Ф. 413, On. 1, Cnp. 557. Apк. 362. 1931.
} 
Колективізація суттєво вплинула і на традиційний погляд грецької етноспільноти щодо жіночої праці. Процес залучення жінок до польових робіт відбувався надзвичайно повільно, навіть протягом 30-х років багато грекинь залишалися вдома. Життя ж тих жінок, які поступово залучалися до колгоспного виробництва, суттєво ускладнилося. Тепер вони були змушені витрачати багато часу на роботу на полях та на фермах, в той час, як на звичайні домашні справи, такі як догляд за господарством, дітьми, приготування їжі, майже не залишалося часу ${ }^{1}$.

3 розгортанням колективізації розпочалося поступове витіснення грецьких представників із керівних посад у сільських радах. Партійне керівництво намагалося не допустити так званий «заможний елемент» грецького селянства до влади. Велика кількість грецького населення була позбавлена виборчого права, до чорних списків попадали «куркульські елементи», які насправді становили велику частину грецького працездатного населення.

Етап пришвидшеної колективізації, для багатьох селян став початком жахливого періоду. Місцеве керівництво зрозуміло, що, не дивлячись на певні успіхи радянської пропаганди серед народу, більшість селян все одно добровільно не відмовиться від власного майна, а тому методи колективізації все частіше ставали насильницькими та примусовими. В багатьох регіонах України селяни організовували виступи і навіть проганяли партійних активістів, намагаючись зупинити невблаганний поступ колективізації, як власного грабунку. В грецьких селах Приазов'я обійшлося без серйозних заворушень, проте це не означає, що селяни добровільно розставалися з власним майном. Посилювався тиск на місцеві органи і з боку держави. Вони повинні були будь за що завершити колективізацію, в іншому випадку їм також загрожувало покарання - догани або звільнення, або навіть притягнення до судової відповідальності. На початку 1931 року тиск ще більше посилився. В кінці зими 1931 року до районів прибули уповноважені РНК з метою прискорення хлібозаготівлі. В подальшому було рекомендовано при необхідності застосовувати примусове вилучення хліба у середняцьких господарств, які не виконували контрактаційні договори. Штрафним санкціям піддавалися також і голови сільрад та місцеві партсекретарі. Тим з них, хто мав заборгованість, було заборонено брати участь у районних з'їдах рад².

На початку 30-х років радянські газети продовжували рясніти гучними заголовками про успіхи колективізації та про спільний поступ до світлого майбутнього, проте насправді картина була геть іншою. У місцевих органах влади часто густо було поширене пияцтво, безвідповідальність. У звітах та доповідях, що надходили з місцевих центрів, частіше за все провали хлібозаготівлі або іншого пояснювали куркульською шкодою. Проте насправді звичайне українське село, в тому числі і села 3 переважаючим грецьким населенням, швидко рухалися в напрямку господарчого колапсу та розрухи. Через нестачу харчів та поганий догляд почався падіж великої рогатої худоби, коней. У селянському суспільстві все сильніше відчувалася серйозна криза, яка погрожувала стати глибокою та всеохоплюючою.

Не дивлячись на те, що преса продовжувала пропагувати серед народу ударницькі настрої, намагаючись розвинути трудову активність та змагання між працюючими, у багатьох грецьких селах панували пасивність та апатія. Багато селян втрачали зацікавленість у роботі. Про поганий розвиток ударництва неодноразово повідомлялося у звітах про стан грецьких районів. У часи гострої кризи чимало людей з селищ залишало власні домівки і направлялися до міста, аби знайти там якусь роботу і не голодувати. У селах почали з'являтися покинуті будинки, а самі села замість жвавих центрів колективної праці почали нагадувати поселення зневірених і втомлених від життя селян, які боролися за виживання ${ }^{3}$.

Деструктивна та нищівна соціальна політика держави запроваджувалася за допомогою репресій і тиску. На початку 30-х років внаслідок злочинної політики Радянського уряду на території УРСР спалахнув незвичайний голод, який торкнувся також і грецького населення.

Навесні 1933 року, коли почалася засівна кампанія, радянське керівництво, аби змусити виснажених людей працювати, почало годувати лише тих, хто працював у полі. Така ситуація змусила на початку 1933 року йти в поле усіх, хто міг триматися на ногах. Районні органи влади виробили

\footnotetext{
${ }^{1}$ Білан, С. О. (2013). Життя та побут украӥнських селян в 30-х роках ХХ століття: монографія. Ніжин: ПП Лисенко, 256.

2 Якубова, Л. Д. (2011). Повсякденне життя етнічних меншин радянської України у міжвоєнну добу. Київ: Інститут історії України, 151.

3 Терентьєва, Н., Балабанов, К. (2008). Греки в Україні: історія і сучасність. Навчальний посібник для студентів вищих навчальних закладів. Київ: Аквілон-Плюс, 187.
} 
чіткий регламент за яким: годували лише тих, хто працював у полі, і позбавляли харчування тих, хто запізнювався або не виконував норм відробітку ${ }^{1}$.

Вкрай скрутне становище на початку 1933 року змусило вийти в поле і грецьких жінок, навіть тих, хто був з найбільш консервативних родин. Тепер уже не було змоги дотримуватися традицій, усі йшли працювати задля того, щоб вижити і щоб прогодувати дітей. Влітку задля вирощування врожаю масово використовувалася дитяча праця, працювали всі, хто міг це робити. Наркомзем УСРР встановив жорстку норму на відпрацювання у прополці- половина гектара на особу - i суворо стежили за тим, щоб ця норма виконувалася. У деяких грецьких колгоспах Приазов’я встановлювалися більш послаблені норми, які реально було виконати селянам (наприклад, у грецькому радгоспі «Сартана» було встановлено норму в 1 гектар на 8 працюючих), проте влада, як правило, стежила за діяльністю таких колгоспів і не дозволяла їм цього робитиㄹ․

Газети протягом складного 1933 року продовжують рясніти заголовками про боротьбу зі шкідниками, куркулями. Повідомлялося, ніби це вони заважають вдалій урожайній кампанії. Наводилися приклади показового покарання «куркулів» та «шкідників», якими називали всіх, хто хоч якось не міг виконувати встановлені трудонорми.

Зрештою роки постійної примусової колективізації, нужденності та голоду призвели до того, що менталітет селянина став змінюватися. Все більше поширилося відчуття необхідності постійної роботи в колгоспі. Трудящі маси стали не тільки намагатися показати свої трудові досягнення, але i стежили за оточуючими, намагалися берегти колгоспне добро, худобу. Почастішали повідомлення у газетах про несумлінне ставлення до своїх обов'язків, про показові покарання та суди. Після виходу постанови про зниження цін, відбувається ряд мітингів, присвячених вихвалянню радянської влади та іiї політики, подібні заяви звучать і на місцевих зборах. Поступово, крок за кроком, радянська влада досягала своїх цілей, виховуючи у селян менталітет трударя-колгоспника. Тих же селян, хто не хотів підкоритися, або не міг цього зробити через певні обставини, просто перемолола радянська репресивна машина.

Висновки: Проголошений у 1927 році курс на колективізацію мав в перспективі повністю позбавити селян приватного господарства, проте темпи колективізації на практиці виявилися не такими швидкими, як того планувало керівництво. У відповідь на це в 1929 році було розгорнуто прискорену колективізацію та боротьбу з так званими «шкідниками» і «куркулями», до яких записали всіх незгодних селян, та всіх тих, хто мав хоча б невелике, нажите власною працею, господарство. Жертвами такої боротьби стали тисячі простих селян, яких заарештовували та висилали у віддалені місцевості. Грецьке населення Приазов'я як одне з найбільш заможних у регіоні в повній мірі відчуло це на собі і дуже сильно постраждало від репресій. Така ситуація призвела до серйозної кризи у селянському суспільстві на початку $30-x$ років, яка призводила до провалів хлібозаготівель, поширенню безвідповідальності, пасивності та господарчого колапсу. Період примусової колективізації відбився і на менталітеті грецького селянина, який поступово ставав все більше схожим на типового радянського трудівника.

\section{References:}

1. Animitsa, Ye. G., Antonova, L. G. (2010). Maloianisol: istoriia, sobytiia, sudby (1780-2010) [Maloyanisol: history, events, destinies (1780-2010)]. Yekaterinburg: Publishing House of the Ural State Economic University. [in Russian].

2. Bilan, S. O. (2013). Zhyttia ta pobut ukrainskykh selian v 30-kh rokakh XX stolittia: monohrafiia [Life and way of life of Ukrainian peasants in the 30s of the XX century: monograph]. Nizhyn: PP Lysenko. [in Ukrainian].

3. Dmytriienko, M., Lytvyn, V., Tomozov, V., Yakovlieva, L., Yas, O. (2000). Hreky na ukrainskykh terenakh: narysy z etnichnoi istorii [Greeks in Ukraine: Essays on Ethnic History]. Kyiv: Lybid. [in Ukrainian].

4. Yakubova, L. (ed.) (2008). Istoriia povsiakdennosti v yii etnichnomu vymiri: spohady hreka-komunista [The history of everyday life in its ethnic dimension: the memories of a Greek communist]. Kyiv. [in Ukrainian].

5. Nasedkina, L. D. (1992). Hretski natsionalni silrady ta raiony v Ukraini (druha polovyna 20-kh-30-ti roky XX stolittia) [Greek national village councils and districts in Ukraine (second half of the 1920s-1930s)]. Ukrainskyi istorychnyi zhurnal [Ukrainian Historical Journal], 6, 64-72. [in Ukrainian].

6. Patryliak, B. K. (2011). Selianskyi opir kolektyvizatsiinym zakhodam radianskoi vlady v USRR u 1931-1932 rr. [Peasant resistance to the collectivization measures of the Soviet government in the USSR in 1931-1932.] Hileia:

\footnotetext{
${ }^{1}$ Якубова, Л. Д. (2011). Повсякденне життя етнічних меншин радянської Украйни у міжвоєнну добу. Київ: Інститут історії України, 221.

2 Там само, 223.
} 
naukovyi visnyk. Zbirnyk naukovykh prats [Hileya: scientific bulletin: Collection of scientific works], 52, 29-36. [in Ukrainian].

7. Temyr, S. K. (2007). Ocherky ob istoryy sela Staromlynovka [Essays on the history of the village of Staromlinovka]. Mariupol: Federatsyia hrecheskykh obshchestv Ukrayny. [in Russian].

8. Terentieva, N., Balabanov, K. (2008). Hreky v Ukraini: istoriia i suchasnist. [Greeks in Ukraine: history and modernity]. Navchalnyi posibnyk dlia studentiv vyshchykh navchalnykh zakladiv [A textbook for students of higher educational institutions]. Kyiv: Akvilon-Plius. [in Ukrainian].

9. Tsentralnyi derzhavnyi arkhiv vyshchykh orhaniv vlady ta upravlinnya Ukrayiny [Central state archives of supreme bodies of power and government of Ukraine]. F. 413. Op. 1. Spr. 444. 1929. [in Ukrainian].

10. Tsentralnyi derzhavnyi arkhiv vyshchykh orhaniv vlady ta upravlinnya Ukrayiny [Central state archives of supreme bodies of power and government of Ukraine]. F. 413. Op. 1. Spr. 463. 1929. [in Ukrainian].

11. Tsentralnyi derzhavnyi arkhiv vyshchykh orhaniv vlady ta upravlinnya Ukrayiny [Central state archives of supreme bodies of power and government of Ukraine]. F. 413. Op. 1. Spr. 557. 1931. [in Ukrainian].

12. Yakubova, L. (2011). Povsiakdenne zhyttia etnichnykh menshyn radianskoi Ukrainy u mizhvoiennu dobu. [Everyday life of ethnic minorities in Soviet Ukraine in the interwar period]. Kyiv: Instytut istorii Ukrainy. [in Ukrainian].

13. Yakubova, L. D. (2004). Sutsilna kolektyvizatsiia v selakh etnichnykh menshyn. 1930-1935 rr. [Total collectivization in ethnic minority villages. 1930-1935]. Problemy istorii Ukrainy: fakty, sudzhennia, poshuky [Problems of Ukrainian history: facts, opinions, searches]. Kyiv: Instytut istorii Ukrainy NAN Ukrainy, 11, 370-412. [in Ukrainian]. 